\title{
Water purification using porous ceramics prepared by recycling volcanic ash and waste glass
}

\author{
Tomohiro Ando $^{1} \cdot$ Yuki Fujita $^{1}$ - Mayu Kakinaga ${ }^{1}$ Nobuto Oka ${ }^{1} \cdot$ \\ Tetsuaki Nishida ${ }^{1}$
}

Received: 27 December 2016/Accepted: 27 April 2017/Published online: 6 May 2017

(c) The Author(s) 2017. This article is an open access publication

\begin{abstract}
Water purification was examined using porous ceramics prepared by sintering a powder mixture of volcanic ash, waste glass and a small amount of wood charcoal. The porous ceramics had cross-linked 3D-channels of which the diameter ranged from several $\mathrm{nm}$ to several $\mu \mathrm{m}$. Three kilograms of porous ceramics placed in $90 \mathrm{~L}$ of circulating artificial seawater, in which several tropical fishes were actually living under aeration, caused a decrease in COD from 23.8 to $13.1 \mathrm{mg} \mathrm{L}^{-1}$ in a week. The number of coliform bacteria was almost constant in a range of 52-65 mL $\mathrm{mL}^{-1}$ despite that a lot of excrements were discharged frequently. The number of the coliform bacteria in the seawater examined "without the tropical fishes" decreased from 900 to $1 \mathrm{~mL}^{-1}$ in 2 weeks, and COD decreased from 37.9 to $7.9 \mathrm{mg} \mathrm{L}^{-1}$. It proved that several aerobic bacteria proliferating in the macropores inside the porous ceramics could effectively decompose several organic materials.
\end{abstract}

Tetsuaki Nishida

nishida@fuk.kindai.ac.jp; tnishida3730@gmail.com

1 Department of Biological and Environmental Chemistry, Faculty of Humanity-oriented Science and Engineering, Kindai University, 11-6 Kayanomori, Iizuka, Fukuoka 820-8555, Japan

\section{Graphical abstract}

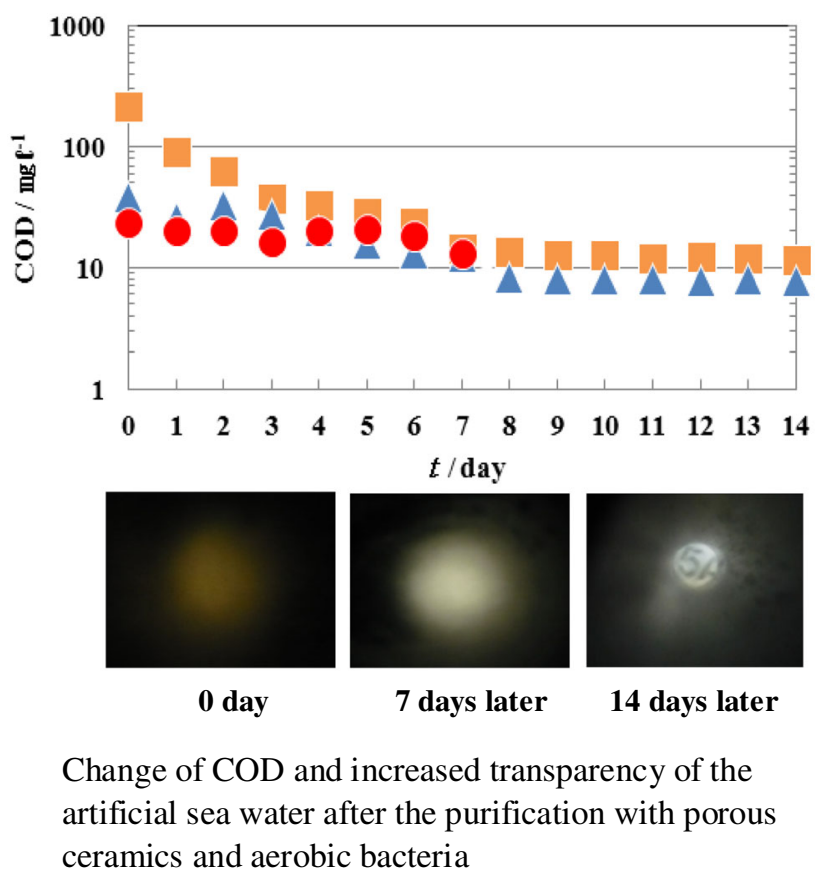

Keywords Water purification - Porous ceramics . Recycling · Volcanic ash · Waste glass · Mössbauer spectroscopy

\section{Introduction}

Several million tons of volcanic ashes erupt every year from Volcano Sakurajima, Kagoshima Pref., Japan. Recycling of volcanic ashes is limited to preparing small 
amounts of brocks, cement, porcelains, etc. Rest of the volcanic ashes is buried at certain waste disposal sites. It is known that most part $(>70 \%)$ of volcanic ash is heat-resistant soda-lime aluminosilicate glass. It was reported that the chemical composition of the volcanic ash ("black ash") ejected from Volcano Sakurajima in 1974-1978 was: $\mathrm{SiO}_{2}$ (58-60\%), $\quad \mathrm{Al}_{2} \mathrm{O}_{3}$ (17-18\%), $\mathrm{CaO}(6.1-6.4 \%), \quad \mathrm{FeO}$ (4.8-6.1\%), $\mathrm{Na}_{2} \mathrm{O}$ (3.1-3.3\%), $\mathrm{MgO}(2.5-2.9 \%), \mathrm{Fe}_{2} \mathrm{O}_{3}$ $(0.4-1.9 \%), \mathrm{K}_{2} \mathrm{O}(1.3-1.6 \%)$ and others $(1.3-4.1 \%)$ (Oba et al. 1980). Composition of the volcanic ash used in the present study was: $\mathrm{SiO}_{2}(61 \%), \mathrm{Al}_{2} \mathrm{O}_{3}(17 \%), \mathrm{CaO}(6 \%)$, $\left(\mathrm{FeO}+\mathrm{Fe}_{2} \mathrm{O}_{3}\right)(6 \%), \mathrm{Na}_{2} \mathrm{O}(3 \%), \mathrm{MgO}(3 \%), \mathrm{K}_{2} \mathrm{O}(2 \%)$ and others (2\%) (Nishida 2016). It is noteworthy that these compositions are also close to those reported for lava and volcanic bomb collected in 1946 and 1956, respectively (Oba et al. 1980).

Black color of the volcanic ash ejected from Volcano Sakurajima was ascribed to $\mathrm{FeO}$ (Oba et al. 1980). Mössbauer study of the "black ash" sampled in 1984-1986 showed an apparently asymmetric paramagnetic doublet with isomer shift $(\delta)$ and quadrupole splitting $(\Delta)$ of 1.13-1.14 and 2.06-2.10 $\mathrm{mm} \mathrm{s}^{-1}$, respectively (Nishida et al. 1986). The doublet was assigned to octahedral $\mathrm{Fe}^{\mathrm{II}}$ species that occupied the so-called interstitial sites of the 3D-network of soda-lime aluminosilicate glass which was composed of distorted $\mathrm{SiO}_{4}$ and $\mathrm{AlO}_{4}$ tetrahedra. It was surprising that Mössbauer parameters determined for the white sand "Shirasu", originating from the volcanic ash that erupted ca. 25,000 years ago, were comparable to those of the "black ash" (Nishida et al. 1986). The value of $\delta, 1.08 \mathrm{~mm} \mathrm{~s}^{-1}$, being slightly smaller than that obtained for the "black ash" $\left(1.13-1.14 \mathrm{~mm} \mathrm{~s}^{-1}\right)$, indicates a breakdown or "depolymerization" of the network due to the weathering and formation of nonbridging oxygen or terminal oxygen. This finding suggested that the local structure around $\mathrm{Fe}^{\mathrm{II}}$ atoms in the "black ash" was essentially the same as that of white sand "Shirasu", despite that it had a history of ca. 25,000 years.

About 3.3 million tons of glass bottles, so-called sodalime silicate glass, are released every year in Japan (Suzuki et al. 2006). Seventy percent of them are colorless or of brown color. Although they are recycled or reused as "returnable bottles", the colored ones are discarded at the waste disposal sites. Recycling of the colored bottles is important from the viewpoints of environmental issues and energy-saving. It is well known that the energy cost for the preparation of glass bottle from waste glass by recycling is about $30 \%$ lower than that from raw materials like $\mathrm{Na}_{2}$ $\mathrm{CO}_{3}, \mathrm{CaCO}_{3}$ and $\mathrm{SiO}_{2}$. Another merit of the recycling is a reduced emission of $\mathrm{CO}_{2}$ gas during the manufacturing.

Recycling technology of the volcanic ash to prepare porous ceramics with waste glass was recently registered as a Japanese patent (Nishida 2016). Recycling of coal ash (fly ash) with waste glass was also investigated (Tamaki et al. 2006; Nishida 2009, 2010). Main component of volcanic ash and that of coal ash are known to be heatresistant soda-lime "aluminosilicate" glass composed of alkali oxides, alkaline earth oxides, $\mathrm{Al}_{2} \mathrm{O}_{3}, \mathrm{SiO}_{2}$, etc. In case of the volcanic ash-derived porous ceramics, most appropriate mass ratio between the volcanic ash and waste glass bottle was found to be $5: 2$ on the basis of several experiments in which temperature and duration of the sintering were examined extensively (Nishida 2016). Since volcanic ash and fly ash were composed of heat-resistant soda-lime aluminosilicates, sintering was examined in a temperature range of $950-1100{ }^{\circ} \mathrm{C}$ to prepare as many pores as possible in the molten glassy phase.

When waste glass bottle for soft drinks was recycled as the main component, wood charcoal could be utilized to prepare porous ceramics as a "sub-component" (Nishida 2011). In this case, an appropriate mass ratio between the waste glass to the wood charcoal was found to be in a range of 70:30 to $92: 8$ on the basis of several experiments in which the temperature was examined extensively ranging from 600 to $1050{ }^{\circ} \mathrm{C}$. As a result, the most appropriate sintering temperature was determined to be $800{ }^{\circ} \mathrm{C}$. Related porous ceramics was prepared by recycling the waste glass bottle with bamboo charcoal by sintering a powder mixture with a mass ratio of $80: 20$ at $800{ }^{\circ} \mathrm{C}$ for $60 \mathrm{~min}$ (Nishida et al. 2017a). It is noted that waste glass bottle, i.e., soda-lime silicate glass which was free from heat-resistant $\mathrm{Al}_{2} \mathrm{O}_{3}$, was the main component in these porous ceramics when recycled with wood charcoal or bamboo charcoal.

The characteristic feature of porous ceramics lies in the 3D-channels (tunnels) with diameters of several $\mathrm{nm}$ to several $\mu \mathrm{m}$, which depended on the composition of raw materials and on the sintering temperature. 3D-channels are linked to each other from the surface to the bulk and from the bulk to the back surface. Specific surface of the porous ceramics prepared from coal ash and waste glass was reported to be $0.05-7.5 \mathrm{~m}^{2} \mathrm{~g}^{-1}$, while the bulk density was ca. $1.2 \mathrm{~g} \mathrm{~cm}^{-3}$ (Nishida 2009, 2010). These porous ceramics could absorb more than $20 \%$ of water of their own masses, and the water was reserved inside the 3Dchannels. Size and fraction of the 3D-channels depended on the composition of the raw materials. 3D-channels of several micrometer sizes made it possible for the microbes to proliferate inside the porous ceramics, in which they formed biofilm which played a principal role in the waste water purification.

3D-channels were formed by the linkage of numerous pores embedded in the molten matrix of silicate glass composed of distorted $\mathrm{SiO}_{4}$ tetrahedra. Pores were prepared as a result of the oxidation of carbon to carbon dioxide in the molten glassy phase. The appropriate 
temperature required for the 3D-channel formation depended on the temperature and the duration of sintering. When the temperature was too high, most of the pores were easily collapsed in the molten glassy phase. When the temperature was too low, in contrast, the pore formation was difficult since the glass phase itself did not melt.

More than 10 million tons of coal ashes are released from thermal power plants in Japan since most nuclear power plants have been suspended after Fukushima's natural disaster occurred in 2011. According to the statistics data (Japan Coal Energy Center 2016), 12.6 million tons of coal ashes were released in 2014. Porous ceramics prepared by recycling coal ash (fly ash) and waste glass bottle had 3D-channels with diameters ranging from several $\mathrm{nm}$ to $80 \mathrm{~nm}$ (Nishida 2010). Purification test using the porous ceramics (750 g) was successfully achieved in artificial waste water (15 L) containing $100 \mathrm{~mL}$ of milk and $15 \mathrm{~mL}$ of active sludge. In this case, BOD (biochemical oxygen demand) decreased from $740-800$ to $2.6 \mathrm{mg} \mathrm{L}^{-1}$ with a cleaning rate of 99.0-99.7\%, and COD (chemical oxygen demand) from $250-270$ to $7.5-10 \mathrm{mg} \mathrm{L}^{-1}$ with a cleaning rate of $96-99 \%$ in one or 2 weeks (Nishida 2010). These cleaning rates were comparable to those determined from the experiments using "white corals" which are used for water purification in the fish tank or fish reserve; i.e., $99.6 \%$ from the measurement of BOD and $97.8 \%$ from COD. A blank test without the porous ceramics resulted in a less effective cleaning rate of $95.1 \%$ (BOD) and $80.9 \%$ (COD). Porous ceramics made from waste glass and wood charcoal (Nishida 2010, 2011) also had a high cleaning effect of $99.4 \%$ (BOD) and $98.9 \%$ (COD) when combined with the active sludge under aeration. These results proved that the active sludge with proliferating microbes in the pores of porous ceramics played a principal role in these waste water purification tests.

Different types of porous ceramics will be utilized for several purposes at several facilities. The present study was carried out to evaluate the water-cleaning capability of the porous ceramics prepared by recycling volcanic ash as a main component and waste glass as a sub-component. Feasibility of using porous ceramics for water purification was first examined using artificial seawater circulating under aeration in the water tank, in which several tropical fishes were living and a lot of excrements and organic materials were discharged frequently. For evaluating water purification, change of COD, number of coliform bacteria and transparency of the seawater were examined for one or 2 weeks.

\section{Experimental}

Volcanic ash-derived porous ceramics was prepared by sintering a powder mixture composed of volcanic ash ejected from Volcano Sakurajima and waste glass bottle.
As the waste glass, glass bottle for soft drinks (soda-lime silicate glass) was used having a composition of $\mathrm{Na}_{2} \mathrm{O}$ (15.5 mass\%), $\mathrm{CaO}$ (11.0 mass\%) and $\mathrm{SiO}_{2}$ (73.5 mass\%). Each mixture composed of the volcanic ash and the waste glass with a mass ratio of 5:2 was thoroughly pulverized in a mortar with extra amount (5 or 10 mass $\%$ ) of wood charcoal. The mixture placed in an alumina saggar (box bowl) with an alumina cover was heated from room temperature to a given temperature ranging from 900 to $1000{ }^{\circ} \mathrm{C}$, e.g., $950{ }^{\circ} \mathrm{C}$, in an electric furnace. After sintering for 45-75 $\mathrm{min}$, the temperature of the furnace was gradually decreased to room temperature in more than $3 \mathrm{~h}$.

${ }^{57} \mathrm{Fe}$ Mössbauer measurement was conducted at room temperature (RT) by the conventional constant acceleration method with a source of $370 \mathrm{MBq}$ of ${ }^{57} \mathrm{Co}(\mathrm{Rh})$. A foil of $\alpha$ Fe was used for calibrating the velocity scale of the spectrometer and as a reference of isomer shift $(\delta)$. Spectral analysis was made using a convenient software (Prescher et al. 2012).

Evaluation of the porous ceramics $(3 \mathrm{~kg})$ as a water purification material was conducted using $90 \mathrm{~L}$ of artificial seawater circulating under aeration in a water tank where several tropical fishes were actually living. The water tank was composed of $66 \mathrm{~L}$ of living area and $24 \mathrm{~L}$ of aeration area in which several commercially available aerobic bacteria like Bacillus pumilus were added originally. They are effective for the decomposition of surplus feeds, excrements, urine, ammonia, nitrite ions, etc. Wool mat and psammous "white coral" were used as a physical filter. In addition, subsequent test was conducted in a different water tank $(15 \mathrm{~L})$. In this case, $750 \mathrm{~g}$ of porous ceramics was applied to $15 \mathrm{~L}$ of the artificial seawater which was explored for the experiment with living tropical fishes. Furthermore, water-cleaning capability of the porous ceramics $(750 \mathrm{~g})$ was separately evaluated using artificial "waste water" composed of pure water $(15 \mathrm{~L})$ and $100 \mathrm{~mL}$

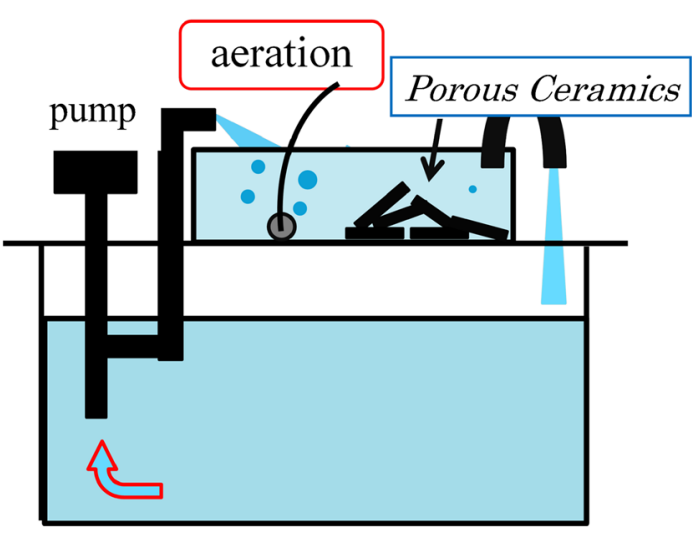

Fig. 1 Experimental setup for water purification using the porous ceramics under aeration 
of commercially available milk. Experimental setup for the water purification test is illustrated in Fig. 1.

Before the COD measurement using $\mathrm{KMnO}_{4}$ solution, chloride ions in the artificial seawater were removed using an equivalent amount of $1.5 \mathrm{M} \mathrm{AgNO}_{3}$ solution. For counting the number of coliform bacteria, $1 \mathrm{~mL}$ of the test solution was poured onto sterilized desoxycholate agar. Coliform bacteria were measured after the cultivation at $35{ }^{\circ} \mathrm{C}$ for $24 \mathrm{~h}$. Transparency of the seawater in which the tropical fishes were living was estimated by pouring it into a vinyl chloride tube with a diameter of $4.3 \mathrm{~cm}$ and a length of 50 or $100 \mathrm{~cm}$, of which the end was sealed with polyethylene sheet and was exposed to light.

\section{Results and discussion}

\section{Characteristics of porous ceramics}

Water absorption rate of the porous ceramics was in a range of 17.6-23.0 $( \pm 0.5) \%$ of their masses when a well pulverized mixture of volcanic ash and waste glass with a mass ratio of 5:2 was sintered with an extra amount (5 mass\%) of wood charcoal at $900-1000{ }^{\circ} \mathrm{C}$ for $45-75 \mathrm{~min}$. Water absorption rates were $17.6-18.3 \%$ when the mixture was sintered at $900{ }^{\circ} \mathrm{C}$ for $45-75 \mathrm{~min}$. The highest water absorption rate of $23.0 \%$ was established when the mixture was sintered at $950{ }^{\circ} \mathrm{C}$ for $45 \mathrm{~min}$. Comparable water absorption rate was achieved when the mixture was heated at $950{ }^{\circ} \mathrm{C}$ for $30 \mathrm{~min}$, but the mechanical strength was not satisfactory. A prolonged sintering at $950{ }^{\circ} \mathrm{C}$ for more than 45 min resulted in an increased strength, but the absorption rate decreased to $20.2 \%$ (60 $\mathrm{min}$ ) and $19.5 \%$ (75 $\mathrm{min})$ since some pores were collapsed in the molten glassy phase to reduce the volume fraction of the 3D-channels. When the mixture was sintered at $1000{ }^{\circ} \mathrm{C}$, water absorption rates were $21.3 \%$ (45 $\mathrm{min})$ and $18.6 \%$ (60 $\mathrm{min})$, while most pores collapsed and disappeared after 75 min sintering. In this study, the highest water absorption rate of 23.0 $( \pm 0.5) \%$ was achieved when the mixture was thoroughly pulverized before the sintering to the grain size of less than 100 mesh. In contrast, it was $17-18 \%$ when the pulverization was not enough. Five or 10 mass $\%$ of wood charcoal was investigated. As a result, 5 mass $\%$ of wood charcoal proved to have higher mechanical strength and higher water absorption rate being suitable for the practical use. Because of its complicated structure of 3D-channels, the volcanic ash-derived porous ceramics showed higher water-holding property and higher mechanical strength.

Specific surface area was estimated by BET method at $77 \mathrm{~K}$ using a small piece of porous ceramics (4.4947 g) filled with $\mathrm{N}_{2}$ gas after the evacuation at $250{ }^{\circ} \mathrm{C}$ for $4 \mathrm{~h}$. It was determined to be $0.5384 \mathrm{~m}^{2} \mathrm{~g}^{-1}$, being comparable to

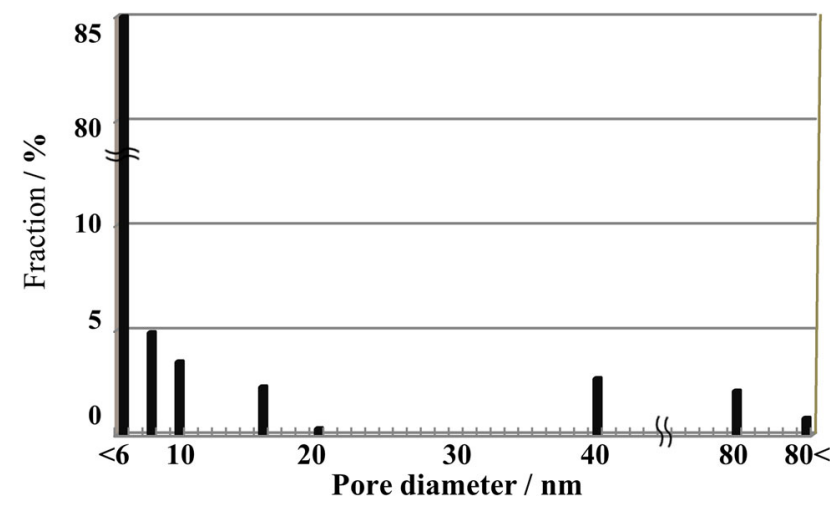

Fig. 2 Micropore-to-mesopore distribution of the porous ceramics prepared by sintering thoroughly pulverized mixture of volcanic ash and waste glass (5:2) with an extra amount (5 mass\%) of wood charcoal

that determined by Langmuir surface area of $0.6118 \mathrm{~m}^{2} \mathrm{~g}^{-1}$. These values were one order of magnitude smaller than those of the porous ceramics prepared by recycling coal ash (fly ash) and waste glass, i.e., $7.525 \mathrm{~m}^{2} \mathrm{~g}^{-1}$ determined by BET and $6.389 \mathrm{~m}^{2} \mathrm{~g}^{-1}$ by Langmuir method (Nishida 2010). Micropore-to-mesopore distribution of the porous ceramics is illustrated in Fig. 2, in which "mesopores" with diameters less than 6, 10, 16 and $40 \mathrm{~nm}$ were detected together with "macropores" with diameters of $80 \mathrm{~nm}$ (ca. 2.1\%) and more than $80 \mathrm{~nm}$ $(0.8 \%)$. As could be understood from Fig. 2, most

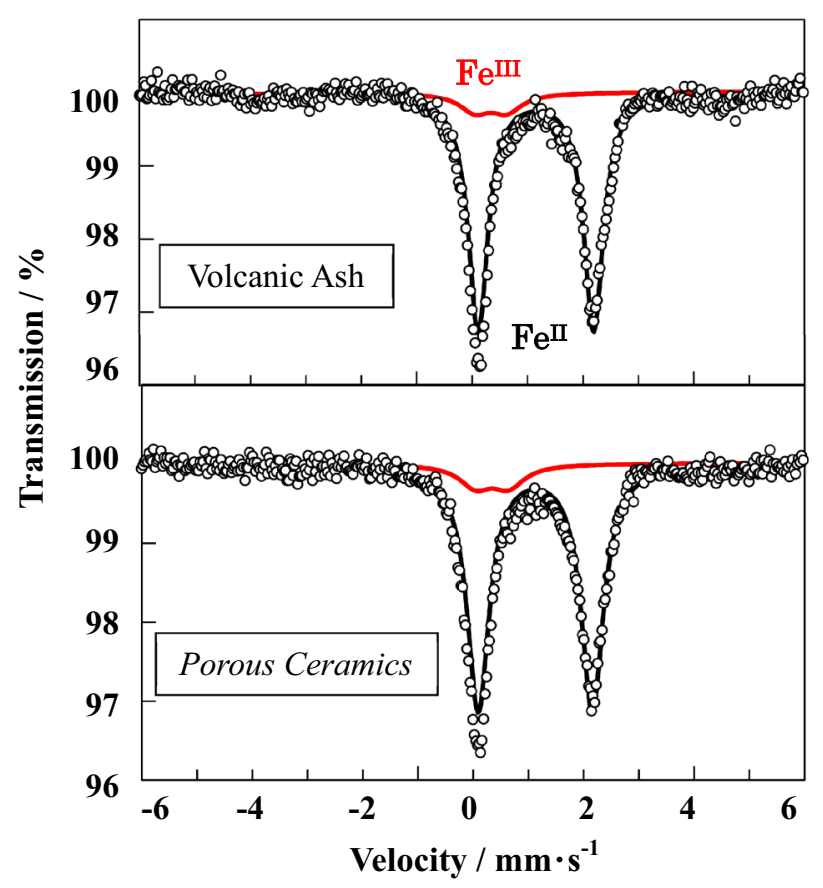

Fig. 3 RT ${ }^{57} \mathrm{Fe}$ Mössbauer spectrum of volcanic ash (top) and that of porous ceramics prepared by sintering thoroughly pulverized mixture of volcanic ash and waste glass (5:2) with an extra amount (5 mass\%) of wood charcoal (bottom) 
micropores and mesopores (86\% in all) had diameters less than $6 \mathrm{~nm}$, and a mean diameter of $3.4 \mathrm{~nm}$. Since a large amount of 3D-channels or "macropore tunnels" with diameters ranging from $50 \mathrm{~nm}$ to several $\mu \mathrm{m}$ were formed, the porous ceramics could absorb $17.6-23.5 \%$ of water of their masses. For determining the cumulative volume of the macropores in the porous ceramics, different method like "mercury press-in method" will be useful.

\section{Mössbauer study of volcanic ash and porous ceramics}

Mössbauer study was carried out for characterizing the raw material and the porous ceramics. Figure 3 (top) depicts RT-Mössbauer spectrum of volcanic ash ejected from Volcano Sakurajima in 2015. The spectrum was quite the same as those reported for the volcanic ashes ejected from Volcano Sakurajima in 1984-1986, in which an apparently asymmetric paramagnetic doublet due to $\mathrm{Fe}^{\mathrm{II}}$ was observed having $\delta$ and $\Delta$ of $1.13-1.14$ and $2.06-2.10 \mathrm{~mm} \mathrm{~s}^{-1}$, respectively (Nishida et al. 1986). In the present study, the Mössbauer spectrum also showed an asymmetric doublet (intense doublet traced with black color) due to $\mathrm{Fe}^{\mathrm{II}}$ with $\delta$ and $\Delta$ of $1.15( \pm 0.01)$ and $2.08( \pm 0.02) \mathrm{mm} \mathrm{s}^{-1}$, respectively. The $\delta$ value of $1.15( \pm 0.01) \mathrm{mm} \mathrm{s}^{-1}$ reflected the presence of distorted $\mathrm{Fe}^{\mathrm{II}} \mathrm{O}_{6}$ octahedra, reflecting that iron (II) atoms occupied so-called interstitial sites in the 3Dnetwork composed of distorted $\mathrm{AlO}_{4}$ and $\mathrm{SiO}_{4}$ tetrahedra, as generally observed in several silicate glasses (Nishida 1997). This means that most iron (II) atoms were playing a role of network modifier (NWM) since numerous $\mathrm{Al}^{\mathrm{III}}$ and $\mathrm{Si}^{\mathrm{IV}}$ atoms played a role network former (NWF) in the glass matrix. Detailed analysis of Mössbauer spectrum revealed an additional absorption peak (weak doublet traced with red color) due to distorted $\mathrm{Fe}^{\mathrm{III}} \mathrm{O}_{4}$ tetrahedra, which had $\delta$ and $\Delta$ of $0.34( \pm 0.01)$ and $0.57( \pm 0.02)$ $\mathrm{mm} \mathrm{s}^{-1}$, respectively. These parameters indicate that iron (III) atoms played a role of NWF, as observed in several inorganic glasses (Nishida 1997; Nishida et al. 2005, 2017b; Kubuki and Nishida 2013). Figure 3a shows that relative absorption area of the distorted $\mathrm{Fe}^{\mathrm{III}} \mathrm{O}_{4}$ tetrahedra was $15.1( \pm 0.5) \%$.

Figure 3 (top) shows very weak absorption peaks appearing at around $-4.0,-3.0$ and $4.6 \mathrm{~mm} \mathrm{~s}^{-1}$, although their absorption intensities were less than the background level. They are ascribed to the absorption peaks due to magnetic hyperfine structure (hfs) of ferrimagnetic $\mathrm{Fe}_{3} \mathrm{O}_{4}$ (Voleník et al. 1975). Similar hfs was observed in the conductive glass prepared by melting powder of coal ash and $\alpha-\mathrm{Fe}_{2} \mathrm{O}_{3}(12-15$ mass $\%)$ at $1100{ }^{\circ} \mathrm{C}$ for $60 \mathrm{~min}$ (Nishida et al. 2005; Kubuki and Nishida 2013). It is interesting that a small amount of ferrimagnetic $\mathrm{Fe}_{3} \mathrm{O}_{4}$ particles were present in the volcanic ash, in addition to several mass \% of paramagnetic iron (II,III).

Figure 3 (bottom) depicts RT-Mössbauer spectrum of the porous ceramics utilized for water purification. Distorted $\mathrm{Fe}^{\mathrm{II}} \mathrm{O}_{6}$ octahedra had $\delta$ and $\Delta$ of $1.12( \pm 0.01)$ and $2.07( \pm 0.02) \mathrm{mm} \mathrm{s}^{-1}$, respectively. They are identical to those obtained for the volcanic ash (Fig. 3, top), within the experimental error. Distorted $\mathrm{Fe}^{\mathrm{III}} \mathrm{O}_{4}$ tetrahedra (weak doublet traced with red color) had $\delta$ and $\Delta$ of $0.34( \pm 0.01)$ and $0.60( \pm 0.02) \mathrm{mm} \mathrm{s}^{-1}$, respectively, which were identical to those of the volcanic ash (Fig. 3, top), within the experimental error. It is concluded that the local structure of distorted $\mathrm{Fe}^{\mathrm{II}} \mathrm{O}_{6}$ octahedra and $\mathrm{Fe}^{\mathrm{III}} \mathrm{O}_{4}$ tetrahedra was kept constant during the preparation of porous ceramics.

It is noteworthy that the absorption area of $15.0( \pm 0.5) \%$ obtained for the distorted $\mathrm{Fe}^{\mathrm{III}} \mathrm{O}_{4}$ tetrahedra in porous ceramics (Fig. 3, bottom) was identical to that of the volcanic ash: $15.1( \pm 0.5) \%$. This finding proves that iron (III) atoms were not reduced to iron (II) during the sintering at $950{ }^{\circ} \mathrm{C}$ for $45 \mathrm{~min}$, despite that the procedure was conducted with extra amount ( 5 mass $\%$ ) of wood charcoal. It is speculated that the sintering temperature was not high enough for the iron (II,III) to cause such a redox reaction, since the main component of the volcanic ash was "heatresistant" soda-lime aluminosilicate. Figure 3 reveals that the wood charcoal only caused the formation of $\mathrm{CO}_{2}$ bubbles in the molten glassy phase and that they linked to each other to produce 3D-channels.

\section{Application of porous ceramics to water purification}

For evaluating the quality of artificial seawater in the tank $\left(25^{\circ} \mathrm{C}\right)$ where several tropical fishes were actually living, COD was measured as illustrated with red circles in Fig. 4. Original COD was determined to be $23.8 \mathrm{mg} \mathrm{L}^{-1}$, which decreased gradually to $13.1 \mathrm{mg} \mathrm{L}^{-1}$ in 1 week with a

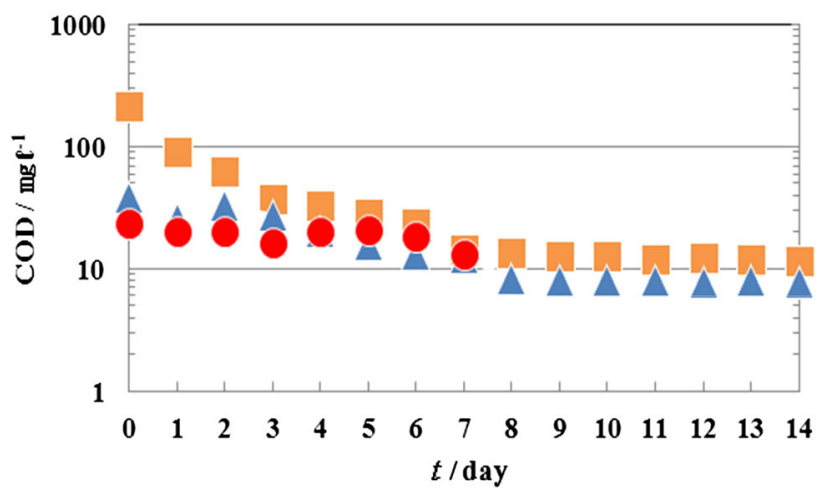

Fig. 4 COD determined for artificial seawater during the purification test with (red circles) and without living tropical fishes (blue triangles). Brown squares were determined separately using separate artificial waste water containing milk 
purification rate of $32.7 \%$, despite that a lot of excrements were discharged frequently by several tropical fishes.

COD of the artificial seawater $\left(25^{\circ} \mathrm{C}\right)$ without the tropical fishes (blue triangles) decreased from 37.9 to $8.3 \mathrm{mg} \mathrm{L}^{-1}$ in a week, yielding a purification rate of $78.1 \%$. After 2 weeks, it finally decreased to $7.9 \mathrm{mg} \mathrm{L}^{-1}$, yielding a purification rate of $79.2 \%$. It is noted that the COD of $7.9 \mathrm{mg} \mathrm{L}^{-1}$ is comparable to the Japanese seawater environmental standard of $8.0 \mathrm{mg} \mathrm{L}^{-1}$ (Ministry of the Environment 2016).

Brown squares plotted in Fig. 4 refer to the COD values determined by a separate water purification test at $25^{\circ} \mathrm{C}$ using $15 \mathrm{~L}$ of artificial waste water under aeration containing $100 \mathrm{~mL}$ of milk and porous ceramics $(750 \mathrm{~g})$. The COD decreased from 216 to 14.6 and $11.6 \mathrm{mg} \mathrm{L}^{-1}$ in 1 and 2 weeks, respectively. The latter value reflects water purification rate of $94.6 \%$. Not to say, water purification rate depends on the mass ratio of the cleaning material (porous ceramics) to the waste water; the higher is the mass ratio, the higher is the purification rate. All the experimental results evidently indicate that the porous ceramics prepared by recycling volcanic ash and waste glass could be a very effective material for water purification. This porous ceramics will be effectively utilized at different facilities like fish farm, fish reserve, household-water treatment, public waste water treatment, etc. It is noted that porous ceramics had better be cleaned mechanically and washed with clean water to remove the waste sludge or excess sludge so that the porous ceramics could keep its intrinsic high water-cleaning capability.

\section{Behavior of coliform bacteria}

Coliform bacteria (coliform bacilli) were counted for the seawater where tropical fishes were actually living. A fixed amount of fish feed was given to the tropical fishes every day. Figure 5 depicts the number of coliform bacteria

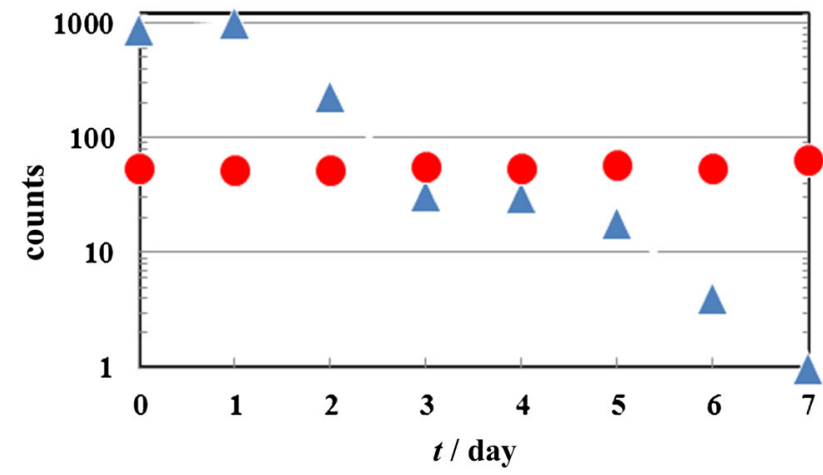

Fig. 5 Number of the coliform bacteria determined during the purification test using artificial seawater with living tropical fishes (red circles), and that determined using the waste seawater collected after the "living" experiment (blue triangles) measured for the artificial seawater in which tropical fishes were living (red circles). Coliform bacteria in the seawater were determined to be $60,53,52,56,54,58,55$ and $65 \mathrm{~mL}^{-1}$ during the first 1 -week experiment. Coliform bacteria in the seawater tank (red circles) proved to be almost constant, except for the seventh day, reflecting satisfactory water-cleaning capability of the porous ceramics. It is considered that aerobic bacteria like Bacillus pumilus, which were originally included in the ingredient of the artificial seawater, could effectively decompose the surplus feeds, excrements, urine, ammonia, nitrite ions, etc. It is considered that the growth of the coliform bacteria was suppressed satisfactorily.

Additional water purification test was conducted in a different water tank, using $15 \mathrm{~L}$ of seawater taken from the seawater tank after 1-week "living" experiment. Coliform bacteria more than $900 \mathrm{~mL}^{-1}$ showed a marked decrease to only "one" $\mathrm{mL}^{-1}$ after 1 week (Fig. 5, blue triangles). In this purification test, $750 \mathrm{~g}$ of porous ceramics was used under aeration without supplying surplus feeds, excrements and urine that were discharged frequently by the tropical fishes in the seawater tank. It is noted that Japanese seawater environmental standard concerning the coliform bacteria is below $1000 \mathrm{MPN}$ (most probable number) per $100 \mathrm{~mL}$ (Ministry of the Environment 2016). Figure 5 verified the very high water purification capability of this porous ceramics.

Three photos of the seawater taken during the purification test with porous ceramics are shown in Fig. 6. Seawater sample taken from the seawater tank was poured into a vinyl chloride tube $(\phi 4.3 \mathrm{~cm}, l 100 \mathrm{~cm})$ of which one end was sealed with transparent polyethylene sheet, and was irradiated with light. As could be understood from Fig. 6, opaque seawater became transparent in 2 weeks so that the letters " $5 \mathrm{~A}$ " written on the polyethylene sheet could be seen clearly. Figures 4, 5, 6 proved that water purification was successfully carried out since several aerobic bacteria living in the macropores of porous ceramics could successfully decompose different organic materials.

\section{Conclusion}

New porous ceramics prepared by recycling volcanic ash and waste glass had mesoporous-to-macroporous structure. COD of the artificial seawater decreased gradually under aeration. Coliform bacteria in the artificial seawater showed almost constant values of 52-65 $\mathrm{mL}^{-1}$ during the 1-week experiment. Opaque seawater became transparent after the purification test of 2 weeks. These results were ascribed to the biological behavior of several aerobic bacteria proliferating in the macropores of the porous 
Fig. 6 Photos of the artificial seawater placed in a vinyl chloride tube $(\phi 4.3 \mathrm{~cm}, \ell$ $100 \mathrm{~cm}$ ) before and after the purification test with "living" fishes

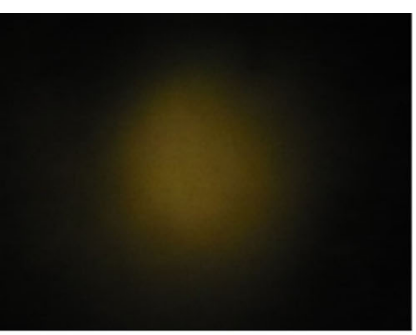

0 day

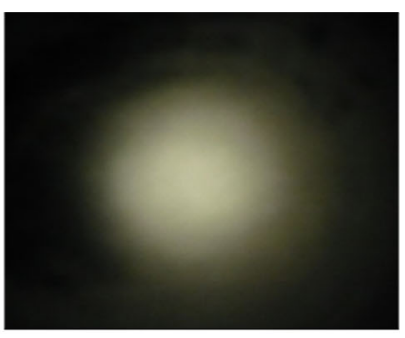

7 days later

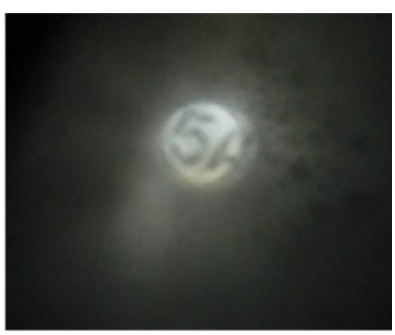

14 days later ceramics. They could successfully decompose several organic materials like surplus feeds, excrements, urine, ammonia, nitrite ions, etc. It proved that the volcanic ash was one of the most appropriate materials for fabricating the porous ceramics which could show very high water purification capability. It is expected that volcanic ashderived porous ceramics could be applied to the purification of drinking water, fish reserve water, fish farm water, etc. It is also expected that this porous ceramics could be applied to microbe carrier, exhausted gas absorber, heat insulating material, etc., by choosing the best composition matching with individual purpose.

Open Access This article is distributed under the terms of the Creative Commons Attribution 4.0 International License (http:// creativecommons.org/licenses/by/4.0/), which permits unrestricted use, distribution, and reproduction in any medium, provided you give appropriate credit to the original author(s) and the source, provide a link to the Creative Commons license, and indicate if changes were made.

\section{References}

Japan Coal Energy Center (2016) Coal Ash Statistics Data. http:// www.jcoal.or.jp/ashdb/ashstatistics/H27_ashstatistics_r1.pdf. Accessed 24 Dec 2016. (in Japanese)

Kubuki S, Nishida T (2013) Water purification and characterization of recycled iron-silicate glass. In: Sharma VK, Klingelhöfer G, Nishida $\mathrm{T}$ (eds) Mössbauer spectroscopy-applications in chemistry, biology and nanotechnology, Chapter 31, Wily, Hoboken, pp 595-607

Ministry of the Environment (Japan) (2016) Japanese seawater environmental standard. http://www.env.go.jp/kijun/wt2-2.html. Accessed 24 Dec 2016. (in Japanese)

Nishida T (1997) Mössbauer spectroscopy of inorganic glasses. In: Vértes A, Homonnay Z (eds) Mössbauer spectroscopy of sophisticated oxides, Chapter 2. Akadémiai Kiadó, Budapest, pp 27-87

Nishida T (2009) Japanese Patent No. 4269011

Nishida T (2010) Science education combined with the invention and innovation of materials science. Res. Rep. Kinki University. (Kayanomori) 13:7-12 http://id.nii.ac.jp/1391/00011463/. Accessed 24 Dec 2016 (in Japanese)

Nishida T (2011) Japanese Patent No. 4817367

Nishida T (2016) Japanese Patent No. 5959832

Nishida T, Ogata M, Takashima Y, Shinno I (1986) Mössbauer spectroscopic study of volcanic glasses ejected from Volcanos Sakurajima and Aso. Mem Fac Sci Kyushu Univ Ser C15(2):235-242

Nishida T, Tokunaga M, Sugata Y, Kubuki S (2005) Mössbauer study of semiconducting and ferrimagnetic fly ash-recycled glass. J Radioanal Nucl Chem 266(2):171-175

Nishida T, Morimoto A, Yamamoto Y, Kubuki S (2017a) Waste water purification using new porous ceramics prepared by recycling waste glass and bamboo charcoal. Appl Water Sci. doi:10.1007/s13201-017-0561-1

Nishida T, Izutsu Y, Fujimura M, Osouda K, Otsuka Y, Kubuki S, Oka N (2017b) Highly conductive barium iron vanadate glass containing different metal oxides. Pure Appl Chem. doi:10.1515/ pac-2016-0916

Oba N, Tomita K, Yamamoto M, Ohsako N, Inoue K (1980) Mineral and chemical compositions and mechanism of formation of volcanic ashes from Sakurajima Volcano, Kyushu, Japan. J Miner Petrol Econ Geol 75(10):329-336 (in Japanese)

Prescher C, McCammon C, Dubrovinsky L (2012) MossA: a program for analyzing energy-domain Mössbauer spectra from conventional and synchrotron sources. J Appl Crystallogr 45:329-331

Suzuki H, Itasaka Y, Makino K (2006) Heat and mechanical properties of waste glass aggregate as a base course material for taking measures of heat island. Jpn Geotech J 1(3):85-93 (in Japanese)

Tamaki J, Kubuki S, Nishida T (2006) Water purification with porous ceramics. Res Rep Kinki Univ (Kayanomori) 5:7-12. http://id. nii.ac.jp/1391/00015006/. Accessed 24 Dec 2016 (in Japanese)

Voleník K, Seberíni M, Neid J (1975) A Mössbauer and X-ray diffraction study of nonstoichiometry in magnetite. Czech J Phys B 25(9):1063-1071 